\title{
PENGARUH KONEKSI POLITIK, GOOD CORPORATE GOVERNANCE DAN KINERJA KEUANGAN TERHADAP TAX AVOIDANCE
}

\author{
Laras Putri Maidina ${ }^{1}$, Lela Nurlaela Wati ${ }^{2 *}$ \\ ${ }^{1,2}$ STIE Muhammadiyah Jakarta, larasputrimaidina08@gmail.com, \\ lela@stiemj.ac.id(Corresponding Author)
}

\begin{abstract}
ABSTRAK
Tujuan dari penelitian ini adalah untuk menguji pengaruh Koneksi Politik, Good Corporate Governance, dan Kinerja Keuangan terhadap Tax Avoidance. Metode penelitian yang digunakan adalah metode kuantitatif. Penelitian ini menggunakan data 45 perusahaan manufaktur yang terdaftar Index Stock Exchange (IDX) selama periode 2014 sampai dengan 2018. Sampel diambil dengan metode purposive sampling dan yang memenuhi kriteria pemilihan sampel. Data diolah dengan software Eviews Versi 9 menggunakan metode Generalized Least Square (GLS). Hasil menunjukkan bahwa Koneksi Politik dan Kinerja Keuangan memiliki pengaruh positif terhadap Tax Avoidance, ini menunjukkan bahwa masih ada perusahaan yang melakukan praktik penghindaran pajak. Corporate Governance tidak berpengaruh terhadap Tax Avoidance, yang berarti keberadaan Corporate Governance efektif dalam usaha mencegah praktik tax avoidance.
\end{abstract}

Kata Kunci: Tax Avoidance, Koneksi Politik, Good Corporate Governance, Kinerja Keuangan

\begin{abstract}
The purpose of the study was to test the influence of Political Connections, Good Corporate Governance, and Financial Performance on Tax Avoidance. The research method used is a quantitative method. The study used data of 45 manufacturing companies listed Index Stock Exchange (IDX) during the period 2014 to 2018. Samples are taken by the purposive sampling method and which meets the criteria for sample selection. Data is processed with Version 9 Eviews software using the Generalized Least Square (GLS) method. Results show that Political Connection and Financial Performance have a positive influence on Tax Avoidance, this suggests that there are still companies that practice tax evasion. Corporate Governance has no effect on Tax Avoidance, meaning the existence of Corporate Governance is effective in attempting to prevent tax avoidance practices.
\end{abstract}

Keywords: Tax Avoidance, Political Connection, Good Corporate Governance, Financial Performance

Naskah diterima: 24-04-2020, Naskah dipublikasikan: 30-11-2020

\section{PENDAHULUAN}

Tax avoidance adalah tindakan mengambil keuntungan dengan memanfaatkan kelemahan hukum yang ada untuk mengecilkan pajak terutang (Prebble et. al. (2012). Di satu sisi penghindaran pajak diperbolehkan, tapi di sisi yang lain penghindaran pajak tidak diinginkan. Dalam konteks pemerintah Indonesia, telah dibuat berbagai aturan guna mencegah adanya penghindaran pajak. (Setiani, 2016).

Fenomena penghindaran pajak di Indonesia, berdasarkan data yang disampaikan oleh menteri keuangan pada tahun 2016 mencatat ada ada sekitar 2.000 perusahaan berkategori 
Penanaman Modal Asing (PMA), yang tidak membayar pajak dalam 10 tahun terakhir. Perusahaan tersebut terbagi pada banyak sektor, salah satunya sektor manufaktur. Menurut perhitungan atau pemeriksaan pajak, perusahaan tersebut harus membayar rata-rata Rp. 25 miliar setahun (finance.detik.com).

Berdasarkan data Direktorat Jenderal Pajak, efektivitas pemungutan pajak terus mengalami penurunan dan kenaikan dari tahun 2014 hingga 2018 dikarenakan pemungutan pajak di Indonesia masih banyak mengalami kendala dan belum optimal. Efektifitas pemungutan pajak dapat dilihat pada Tabel 1 berikut.

Tabel 1. Efektivitas Pemungutan Pajak di Indonesia

\begin{tabular}{|c|c|c|c|}
\hline Tahun & Target & Realisasi & $\begin{array}{c}\text { Efektifitas } \\
\text { Pemungutan } \\
\text { Pajak }\end{array}$ \\
\hline 2014 & Rp. 1.072,39 Triliun & Rp. 985,13 Triliun & $91,56 \%$ \\
\hline 2015 & Rp. 1.294,26 Triliun & Rp. 1.060,83 Triliun & $81,96 \%$ \\
\hline 2016 & Rp 1.355,20 Triliun & Rp. 1.105,73 Triliun & $81,59 \%$ \\
\hline 2017 & Rp. 1.283,57 Triliun & Rp. 1.151,03 Triliun & $89,67 \%$ \\
\hline 2018 & Rp. 1.424,00 Triliun & Rp. 1.315,15 Triliun & $92,24 \%$ \\
\hline
\end{tabular}

Sumber: pajak.go.id

Tabel diatas dapat disimpulkan bahwa efektivitas pemungutan pajak di Indonesia periode 2014-2018 realisasinya beebeda dari target yang seharusnya. Besarnya realisasi penerimaan negara dari sektor pajak pada tahun 2014 adalah sebesar 91,56\%, tahun 2015 sebesar 81,96\%, tahun 2016 sebesar 81,59\%, tahun 2017 sebesar 89,67\% dan tahun 2018 sebesar 92,24\%. Target pajak yang tidak tercapai dapat disebabkan oleh berbagai faktor dimana salah satunya karena adanya tindakan pengelolaan beban perpajakan oleh perusahaan. Tindakan pengelolaan beban pajak merupakan akibat adanya kepentingan yang berbeda antara perusahaan dan pemerintah. Upaya ini dalam rangka untuk meminimalisasi besarnya pajak dengan tidak menunjukkan keuntungan yang sesungguhnya (Mughal dan Akram, 2012).

Dalam penelitian ini faktor pertama yang mempengaruhi tax avoidance adalah koneksi politik. Dunia bisnis sangat erat kaitannya dengan politik, hal ini disebabkan karena berhasilnya suatu bisnis tidak terlepas dari adanya pengaruh politik. Perusahaan dikatakan terkoneksi politik apabila perusahaan dengan cara-cara tertentu memiliki keterikatan secara politik atau berusaha menjalin hubungan kedekatan dengan politisi atau pemerintah (Wati, 2017). Penelitian yang dilakukan koneksi politik diukur dengan menggunakan dummy untuk menilai ada tidaknya koneksi politik dalam perusahaan. Banyak penelitian-penelitian mencoba menjelaskan pengaruh koneksi politik pada praktik tax avoidance. Namun, hasil yang diperoleh masih berbeda-beda. Penelitian oleh Christensen et al. (2013) didukung oleh Butje dan Tjondro (2014) dan Munawaroh dan Ramdany (2019) menyatakan koneksi politik memiliki pengaruh positif pada tax avoidance. Sementara Li (2013), Mulyani d.k.k (2013) dan Kim dan Zhang, (2015) yang menyatakan bahwa perusahaan tidak selalu menggunakan koneksi politik dalam praktik penghindaran pajak (tax avoidance). Oleh sebab itu disimpulkan koneksi politik berpengaruh negatif terhadap penghindaran pajak (tax avoidance). Dan menurut Marfu'ah (2015), Murniyana (2018), Sari dan Rawidjo (2019) menyatakan bahwa koneksi politik tidak berpengaruh terhadap tindakan penghindaran pajak (tax avoidance) yang dilakukan oleh perusahaan.

Suatu perusahaan, selain diharapkan untuk tidak melakukan praktik tax avoidance juga dituntut untuk menerapkan corporate governance. Diterapkannya corporate governance dapat meminimalisir adanya praktik tax avoidance. Corporate governance merupakan faktor yang menentukan penilaian yang dimaksud dalam penghematan pajak, artinya perusahaan yang menerapkan mekanisme tersebut secara terstruktur dengan baik akan diikuti tingkat kepatuhan perusahaan untuk memenuhi kewajiban perpajakannya (Sartori, 2010). Corporate Governance akan di ukur dengan menggunakan metode analisis faktor dari komponen - komponen yang 
termasuk dalam Corporate Governance antara lain proporsi dewan komisaris independen dan komite audit.

Proporsi Dewan Komisaris Independen dapat didefinisikan sebagai seorang yang tidak terafiliasi dalam segala hal dalam pemegang saham pengendali (Winata, 2014). Dewan komisaris dalam menjalankan fungsi pengawasan dapat memengaruhi pihak manajemen untuk menyusun laporan keuangan yang berkualitas (Annisa, 2012). Komisaris independen pun telah banyak dilakukan dalam menunjukkan hasil yang berbeda-beda. Menurut Marfirah dan Syam (2016), Sari dan Devi (2018) dan Feranika (2018) menyatakan bahwa komisaris independen berpengaruh positif terhadap tax avoidance. Penelitian serupa juga dilakukan oleh Prakosa (2014), Diantari dan Ulupui (2016) dan Wijayanti dan Merkusiwati (2017) menyatakan bahwa terdapat pengaruh negatif antara komisaris independen terhadap tax avoidance. Berbeda dengan pendapat Cahyono, d.k.k (2016), Fajar (2018) dan Syuhada d.k.k (2019) berpendapat bahwa besar atau kecilnya proporsi dewan komisaris independen tidak mempengaruhi terhadap tindakan penghindaran pajak (tax avoidance) yang dilakukan perusahan.

Selain komisaris independen, ada juga komite audit, keberadaan komite audit dalam suatu perusahaan berfungsi untuk membantu dewan komisaris dalam mengawasi pihak manajemen dalam menyusun laporan keuangan perusahaan. Marfirah dan Syam (2016) menguji pengaruh komite audit terhadap tax avoidance, dan hasilnya menyatakan bahwa komite audit berpengaruh positif terhadap tax avoidance, sedangkan Utari dan Supadmi (2017) dan Madona dan Wijaya (2018) menemukan bahwa komite audit berpengaruh negatif terhadap tax avoidance. Berbeda dengan hasil penelitian yang dilakukan oleh Oktamawati (2017), dan Fajar (2018) menyatakan bahwa komite audit tidak berpengaruh terhadap tax avoidance.

Selain faktor- faktor seperti koneksi politik, komisaris independen dan komite audit yang mempengaruhi praktik penghindaran pajak, terdapat juga kinerja keuangan yang merupakan salah satu faktor yang dapat mempengaruhi penghindaran pajak. Kinerja keuangan perusahaan merupakan suatu gambaran tentang kondisi keuangan perusahaan yang dapat dianalisis dengan alat - alat keuangan. Sehingga dapat diketahui baik atau buruknya keadaan keuangan suatu perusahaan. Salah satu cara untuk melihat kinerja keuangan suatu perusahaan adalah dengan melihat laporan keuangannya. Dalam melihat laporan keuangan suatu perusahaan, maka akan tergambar didalamnya aktifitas perusahaan tersebut. Oleh karena itu laporan keuangan perusahaan merupakan hasil dari sebuah proses akuntansi yang dapat digunakan sebagai alat untuk komunikasi dan juga digunakan sebagai alat pengukur kinerja perusahaan (Fitria, 2018). Untuk menilai kinerja keuangan dan prestasi perusahaan, analisis keuangan memerlukan tolak ukur yaitu rasio atau indeks, yang menghubungkan dua data keuangan yang satu dengan yang lainnya. Analisis dan interpretasi dari macam-macam rasio dapat memberikan pandangan yang lebih baik tentang kondisi keuangan dan prestasi perusahaan. Dengan menggunakan alat analisis berupa rasio akan dapat menjelaskan atau memberikan gambaran tentang posisi keuangan suatu perusahaan terutama apabila angka rasio pembanding yang digunakan sebagai standar (Munawir, 2012). Pada penelitian ini kinerja keuangan akan di ukur dengan menggunakan metode analisis rasio dalam komponen-komponen yang termasuk dalam kinerja keuangan antara lain Profitabilitas dan Leverage.

Komponen yang pertama Profitabilitas. Profitabilitas adalah kemampuan perusahaan dalam menghasilkan laba. Perusahaan besar biasanya akan menghasilkan laba yang tinggi sehingga akan memengaruhi profitabilitas. Profitabilitas perusahaan yang tinggi akan mendorong manajemen untuk menghasilkan pajak optimal dengan meminimalkan beban pajaknya, sehingga perusahaan cenderung melakukan tax avoidance (Nugrahitha, 2018). Penelitian ini memfokuskan pada return on assets (ROA), karena ROA berfungsi untuk mengukur efektivitas perusahaan dalam penggunaan sumber daya yang dimilikinya. Semakin tinggi ROA, semakin tinggi keuntungan perusahaan sehingga semakin baik pengelolaan aktiva perusahaan. Dewinta dan Setiawan (2016) dan Reinaldo (2017) memberikan bukti empiris bahwa profitabilitas berpengaruh positif terhadap tax avoidance. Faizah dan Adhivinna (2017), Handayani (2018), dan Arianandhi dan Ramantha (2018) mengungkapkan bahwa profitabilitas berpengaruh negatif 
terhadap tax avoindace. Marfu'ah (2015) meneliti hal yang sama mengenai pengaruh profitabilitas dan hasilnya menyatakan bahwa profitabilitas tidak berpengaruh terhadap tax avoidance.

Komponen yang kedua yaitu Leverage. Dalam menjalankan aktifitas operasi suatu perusahaan, untuk mengetahui keputusan pendanaan yang dilakukan oleh perusahaan dapat dilihat dari penggunaan struktur utang yang dikenal dengan istilah leverage. Leverage menggambarkan proporsi total utang yang digunakan oleh banyak perusahaan. Didalam suatu perusahaan leverage dikenal dengan tiga jenis yaitu leverage operasi, leverage keuangan dan total leverage. Penggunaan ketiga leverage ini dengan tujuan agar memperoleh keuntungan pada perusahaan (Mayangsari, 2015). Pada penelitian ini penulis menggunakan pengukuran Debt to Asset Ratio (DAR). Leverage merupakan tingkat utang yang digunakan perusahaan untuk melakukan pembiayaan. Penelitian yang dilakukan oleh Annisa (2017),dan Pajriyansyah \& Firmansyah (2017) melakukan penelitian mengenai pengaruh leverage terhadap tax avoidance yang hasilnya membuktikan bahwa leverage berpengaruh positif terhadap tax avoidance. Penelitian Serupa juga dilakukan oleh Dharma (2015) dan Swingly (2015) menyatakan bahwa leverage berpengaruh negatif terhadap tax avoidance. Hal ini betentangan dengan penelitian yang dilakukan oleh Dewinta dan Setiawan (2016) dan Fadila (2017) yang menemukan bahwa leverage tidak berpengaruh terhadap tax avoidance

Berdasarkan latar belakang tersebut, peneliti-peneliti terdahulu masih menghasilkan banyak perbedaan, maka perlu dilakukan penelitian kembali tentang pengaruh koneksi politik, Good Corporate Governance, dan kinerja keuangan terhadap tax avoidance di Indonesia. Penelitian ini bertujuan untuk menguji dan menemukan bukti secara empiris mengenai pengaruh koneksi politik, Good Corporate Governance, dan kinerja keuangan terhadap tax avoidance secara komprehensif.

\section{KAJIAN LITERATUR \\ Teori Agensi}

Dalam teori keagenan menjelaskan tentang dua pelaku ekonomi yang saling bertentangan yaitu prinsipal dan agen. Hubungan keagenan merupakan suatu kontrak dimana satu atau lebih orang (prinsipal) memerintah orang lain (agen) untuk melakukan suatu jasa atas nama prinsipal serta memberi wewenang kepada agen membuat keputusan yang terbaik bagi prinsipal (Ichsan, 2013). Teori agensi merupakan problem keagenan antara pemegang saham (pemilik perusahaan) dengan manajer potensial yang terjadi apabila manajemen tidak memiliki saham mayoritas perusahaan. Pemegang saham menginginkan manajer bekerja dengan tujuan memaksmimumkan kemakmuran pemegang saham. Sebaliknya, manajer perusahaan bisa saja bertindak tidak untuk memaksimumkan kemakmuran pemegang saham, tetapi memaksimumkan kemakmuran mereka sendiri.

\section{Tax Avoidance}

Menurut Zain (2008:50) penghindaran pajak adalah cara mengurangi pajak yang masih dalam batas ketentuan perundang-undangan perpajakan dan dapat dibenarkan, terutama melalui perencanaan pajak. Penghindaran pajak ini juga merupakan suatu proses pengendalian tindakan agar terhindar dari konsekuensi pengenaan pajak yang tidak dikehendaki. Penghindaran pajak bertujuan untuk meminimalkan beban pajak dengan memanfaatkan kelemahan - kelemahan (loopholes) ketentuan perpajakan suatu negara sehingga ahli pajak menyatakan legal karena tidak melanggar peraturan perpajakan.

Adapun rumus untuk menghitung CETR adalah sebagai berikut:

$$
\text { CETR }=\frac{\text { Pembayaran Pajak }}{\text { Laba Sebelum Pajak }}
$$




\section{Koneksi Politik}

Perusahaan berkoneksi politik ialah perusahaan yang dengan cara-cara tertentu mempunyai ikatan secara politik atau mengusahakan adanya kedekatan dengan politisi atau pemerintah (Purwoto, 2011). Pada penelitian ini, dalam menilai ada tidaknya koneksi politik suatu perusahaan menggunakan proksi ada atau tidaknya kepemilikan langsung oleh pemerintah pada perusahaan. Perusahaan yang dimiliki pemerintah dapat diketanhhui dengan melihat kepemilikan saham atas perusahaan diatas 50\%. Koneksi politik diukur dengan variabel dummy. Variabel dummy adalah variabel buatan yang dibuat untuk mengkuantitatifkan data kualitatif dengan memberi kode 0 (nol) atau 1 (satu). Variabel koneksi politik diukur dengan memberikan nilai 1 untuk perusahaan yang terkoneksi politik dan 0 jika perusahaan tidak terkoneksi politik (Wati, 2017; Wati et. al, 2019).

\section{Good Corporate Governance}

Good Corporate Governance merupakan suatu perangkat aturan yang mengatur hubungan antara stakeholder di antaranya pemegang saham, manajer, kreditur, pemerintah, karyawan, serta pihak-pihak yang berkepentingan lainnya baik pada pihak internal maupun pihak eksternal sesuai dengan hak dan kewajiban mereka (Fahmi, 2013). Pengukuran corporate governance dalam penelitian ini menggunakan variabel Komisaris Independen dan Komite Audit.

\section{Komisaris Independen}

Komisaris independen memiliki fungsi pengawasan untuk membuat laporan keuangan lebih objektif dan mendukung pengelolaan perusahaan yang baik (Kurniasih dan Maria, 2013). Kecurangan yang mungkin terjadi dari pelaporan pihak manajemen perusahaan yang dilaporkan, dipercaya akan berkurang dengan adanya komisaris independen. Komisaris independen memiliki tanggung jawab kepentingan pemegang saham, sehingga komisaris independen harus memperjuangkan ketaatan pajak perusahaan agar dapat mencegah praktik tax avoidance (Harto dan Puspita, 2014).

Komisaris independen dapat menggambarkan tingkat independensi dan objeksivitas dewan dalam pengambilan keputusan (Wati, 2017). Sesuai dengan penelitian yang dilakukan oleh Wati et al, (2020), variabel ini menggambarkan persentase proporsi komisaris independen, dengan perhitungan sebagai berikut :

$$
\text { BOARD }=\frac{\text { Jumlah Komisaris Independen }}{\text { Jumlah Anggota Dewan Komisaris }}
$$

\section{Komite Audit}

Komite Audit bertugas untuk memberikan pendapat kepada Dewan Komisaris atas laporan atau hal-hal yang disampaikan oleh direksi kepada Dewan Komisaris, mengidentifikasi hal-hal yang memerlukan perhatian Komisaris, dan melaksanakan tugas-tugas lain yang berkaitan dengan tugas dewan komisaris. Alat pengukuran penelitian ini yang digunakan yaitu jumlah anggota komite audit, semakin banyak jumlah komite audit maka kebijakan tax avoidance akan semakin rendah, tetapi jika jumlah komite audit semakin sedikit maka kebijakan tax avoidance akan semakin tinggi (Chen et al, 2010).

$$
\text { AUDIT }=\frac{\text { Jumlah Komite Audit Independen }}{\text { Jumlah Anggota Dewan Komisaris }}
$$

\section{Kinerja Keuangan}

Kinerja keuangan merupakan gambaran dari pencapaian keberhasilan perusahaancdapat diartikan sebagai hasil yang telah dicapai atas berbagai aktivitas perusahaan yang telah dilakukan. Dapat dijelaskan bahwa kinerja keuangan adalah suatu analisis yang dilakukan untuk 
sejauh mana suatu perusahaan telah melaksanakan dengan menggunakan aturan-aturan pelaksanaan keuangan secara baik dan benar (Fahmi, 2012). Sementara itu menurut IAI (2012), mendefinisikan bahwa kinerja keuangan adalah kemampuan perusahaan dalam mengelola dan mengendalikan sumber daya yang dimilikinya.

\section{Profitabilitas}

Menurut Fahmi (2015) menyatakan bahwa rasio profitabilitas bertujuan untuk mengukur efektivitas kinerja manajemen dengan menganalisis besar dan kecilnya tingkat keuntungan yang diperoleh perusahaan terhadap tingkat penjualan. Sedangkan Kasmir (2014), perusahaan dengan tingkat pengembalian yang tinggi atas investasi menggunakan utang yang relatif kecil karena tingkat pengembalian yang tinggi memungkinkan perusahaan untuk membiayai sebagian besar pendanaan internal. Dengan kata lain, perusahaan dengan laba ditahan yang besar, akan menggunakan laba ditahan terlebih dahulu sebelum memutuskan untuk menggunakan utang.

Profitabilitas dapat di prosikan pada rasio Return on Assest. ROA adalah gambaran kemampuan manajemen untuk memperoleh keuntungan (Wati et al., 2016). ROA dapat diukur dengan perbandingan antara laba bersih dengan total aset pada akhir periode, yang digunakan sebagai indikator kemampuan perusahaan dalam menghasilkan laba dengan menggunakan rumus sebagai berikut (Wati et al., 2016).

$$
\text { ROA }=\frac{\text { Laba Bersih }}{\text { Total Aset }}
$$

\section{Leverage}

Leverage adalah salah satu rasio keuangan yang menggambarkan hubungan antara hutang perushaaan terhadap modal maupun aset perusahaan. Rasio leverage menggambarkan sumber dana operasi yang digunakan oleh perusahaan. Rasio leverage juga menunjukan risiko yang dihadapi perusahaan (Wati et al, 2020)

Dalam penelitian ini leverage diukur dengan rasio total utang terhadap total aset.

$$
D A R=\frac{\text { Total Hutang }}{\text { Total Asset }}
$$

\section{Variabel Kontrol \\ Firm Size}

Ukuran perusahaan merupakan suatu pengukuran yang dikelompokkan berdasarkan besar kecilnya perusahaan, dan dapat menggambarkan kegiatan operasional perusahaan dan pendapatan yang diperoleh perusahaan. Ukuran perusahaan juga dapat mengakibatkan terjadinya penghindaran pajak pada perusahaan. Ukuran perusahaan adalah suatu skala dimana besar kecilnya perusahaan dapat diklasifikasikan dalam berbagai cara, seperti log total aktiva, log total penjualan dan kapitalisasi pasar (Handayani dan Wulandari, 2014).

Ukuran perusahaan umunya dibagi menjadi 3 kategori yaitu large firm, medium firm and small firm. Tahap kedewasaan perusahaan ditentukan berdasarkan total aktiva, semakin besar total aktiva menunjukan bahwa perusahaan memiliki prospek baik dalam jangka waktu yanng relatif panjang (Wati et al, 2020).

SIZE = Logaritma Nutural Total Aset

\section{Sales Growth}

Pertumbuhan penjualan, penjualan merupakan pembelian sesuatu (barang atau jasa) dari suatu pihak kepada pihak lainnya dengan mendapatkan ganti uang dari pihak tersebut (Sugiyarti, 2017). Pertumbuhan penjualan dapat diartikan meningkatnya jumlah penjualan dari tahun sebelumnya yang diakibatkan karena pembelian barang oleh konsumen.

Pertumbuhan penjualan (sales growth) mencerminkan kemampuan perusahaan untuk meningkatkan penjualannya dari waktu ke waktu (Wati et al, 2020). Semakin tinggi tingkat 
pertumbuhan penjualan suatu perusahaan maka perusahaan tersebut berhasil dalam menjalankan strateginya dalam hal pemasaran dan penjualan produk merumuskan pertumbuhan penjualan sebagai berikut:

GROWTH

$$
=\frac{\text { Sales Tahun Sekarang }- \text { Sales Tahun Sebelumnya }}{\text { Sales Tahun Sebelumnya }}
$$

\section{Pengembangan Hipotesis}

Political Connection atau Koneksi politik yang dimiliki membuat perusahaan memperoleh perlakuan khusus, seperti kemudahan dalam memperoleh pinjaman modal, resiko pemeriksaan pajak rendah yang membuat perusahaan makin agresif dalam menerapkan tax planning yang berakibat pada menurunnya transparansi laporan keuangan. Kehilangan investor akibat penurunan transparansi laporan keuangan dapat digantikan dengan peran pemerintah sebagai penyandang dana utama. Selain itu, perusahaan yang memiliki koneksi politik dengan pemerintah yang sedang berkuasa terbukti memiliki tingkat tax avoidance yang signifikan tinggi jika dibandingkan dengan perusahaan sejenis yang tidak memiliki koneksi politik (Kim dan Zhang, 2013).

Butje dan Tjondro (2014) juga menemukan pengaruh positif antara koneksi politik dan penghindaran pajak perusahaan yang digambarkan dengan rendahnya nilai cash effective tax rate. Hal ini didukung oleh Munawaroh dan Ramdany (2019) yang menyatakan bahwa koneksi politik berpengaruh positif terhadap tax avoidance. Berdasarkan hal tersebut, maka hipotesis yang dapat dirumuskan dalam penelitian ini adalah

\section{H1: Koneksi Politik berpengaruh positif terhadap Tax Avoidance}

Penelitian yang dilakukan Prakosa (2014), yang didukung oleh Diantari dan Ulupui (2016), Wijayanti dan Merkusiwati (2017) menyatakan komisaris independen dapat melakukan pengawasan terhadap manajemen perusahaan dalam melakukan perumusan strategi termasuk dalam strategi yang berhubungan dengan pajak. Peningkatan keberadaan komisaris independen dapat mencegah terjadinya penghindaran pajak. Maka, penelitian yang dilakukan oleh penelitipeneliti terdahulu disimpulkan bahwa proporsi komisaris independen berpengaruh negatif pada penghindaran pajak.

Kehadiran komisaris independen dalam perusahaan dapat meningkatkan pengawasan terhadap kinerja dewan direksi serta memperketat pengawasan terhadap manajemen. Pengawasan tersebut dapat membuat manajemen lebih berhati-hati dalam membuat sebuah keputusan dalam menjalankan perusahaan sehingga aktivitas pengurangan jumlah pembayaran pajak yang dilakukan dengan penghindaran pajak dalam diminimalkan. Berdasarkan hal tersebut, maka hipotesis yang dapat dirumuskan dalam penelitian ini adalah.

\section{H2a : Komisaris Independen berpengaruh negatif terhadap Tax Avoidance}

Utari dan Supadmi (2017) membuktikan pengaruh negatif yang dimiliki komite audit terhadap tax avoidance, ini di dukung oleh penelitian dari Madona dan Wijaya (2018), yang menyatakan pengaruh negatif komite audit terhadap tax avoidance. Keberadaan komite audit yang semakin tinggi, menyebabkan corporate governance mengalami peningkatan kualitas perusahaan dan memperkecil terjadinya praktik tax avoidance. Adanya komite audit akan meminimalisir kecurangan dalam pelaporan perpajakan yang dilaporkan. Hipotesis yang dibangun adalah:

\section{H2b : Komite Audit berpengaruh negatif terhadap Tax Avoidance.}

Profitabilitas merupakan gambaran kinerja keuangan perusahaan dalam menghasilkan laba dari pengelolaan aktiva yang dihitung dengan Return On Assets (ROA). Semakin tinggi nilai ROA, maka semakin besar juga laba yang diperoleh perusahaan. Ketika laba yang diperoleh perusahaan membesar, maka jumlah pajak Penghasilan akan meningkat sesuai dengan 
peningkatan laba perusahaan. Jika semakin tinggi laba perusahaan, maka akan dilakukan perencanaan pajak (tax planning) untuk melakukan aktivitas yang mampu mengurangi jumlah kewajiban perpajakan. Apabila perusahaan akan melakukan tax avoidance maka harus semakin efisien dari segi beban sehingga tidak perlu membayar pajak dalam jumlah besar. Semakin besar nilai ROA perusahaan maka semakin rendah Cash ETR, sehingga menunjukkan bahwa tindakan penghindaran pajak (tax avoidance) yang dilakukan oleh perusahaan semakin tinggi. Dapat diasumsikan bahwa perusahaan yang memiliki profitabilitas tinggi cenderung akan melakukan penghindaran pajak (tax avoidance). Dewinta dan Setiawan (2016), dan Reinaldo (2017) menunjukan profitabilitas yang diukur menggunakan profitabilitas memiliki pengaruh positif terhadap penghindaran pajak (tax avoidance).

\section{H3a : Profitabilitas berpengaruh positif terhadap Tax Avoidance.}

Leverage adalah salah satu rasio keuangan yang menggambarkan hubungan antara hutang perusahaan terhadap modal maupun aset perusahaan. Rasio leverage menggambarkan sumber dana operasi yang digunakan oleh perusahaan. Rasio leverage juga menunjukan risiko yang dihadapi perusahaan (Gusti, 2013). Penelitian yang dilakukan Dharma (2015), menyatakan leverage berpengaruh negatif pada tax avoidance. Tingginya tingkat leverage akan menurunkan tingkat tax avoidance karena semakin tinggi leverage maka perusahaan cenderung meningkatkan laba. Sejalan dengan penelitian yang dilakukan Swingly (2015) yang menyatakan leverage berpengaruh negatif pada tax avoidance. Maka hipotesis yang dapat dirumuskan dalam penelitian ini adalah.

\section{H3b : Leverage berpengaruh negatif terhadap Tax Avoidance.}

Berdasarkan uraian di atas, dapat dibuat suatu kerangka pemikiran teoritis yang menggambarkan variabel-variabel yang mempengaruhi penghindaran pajak yaitu:

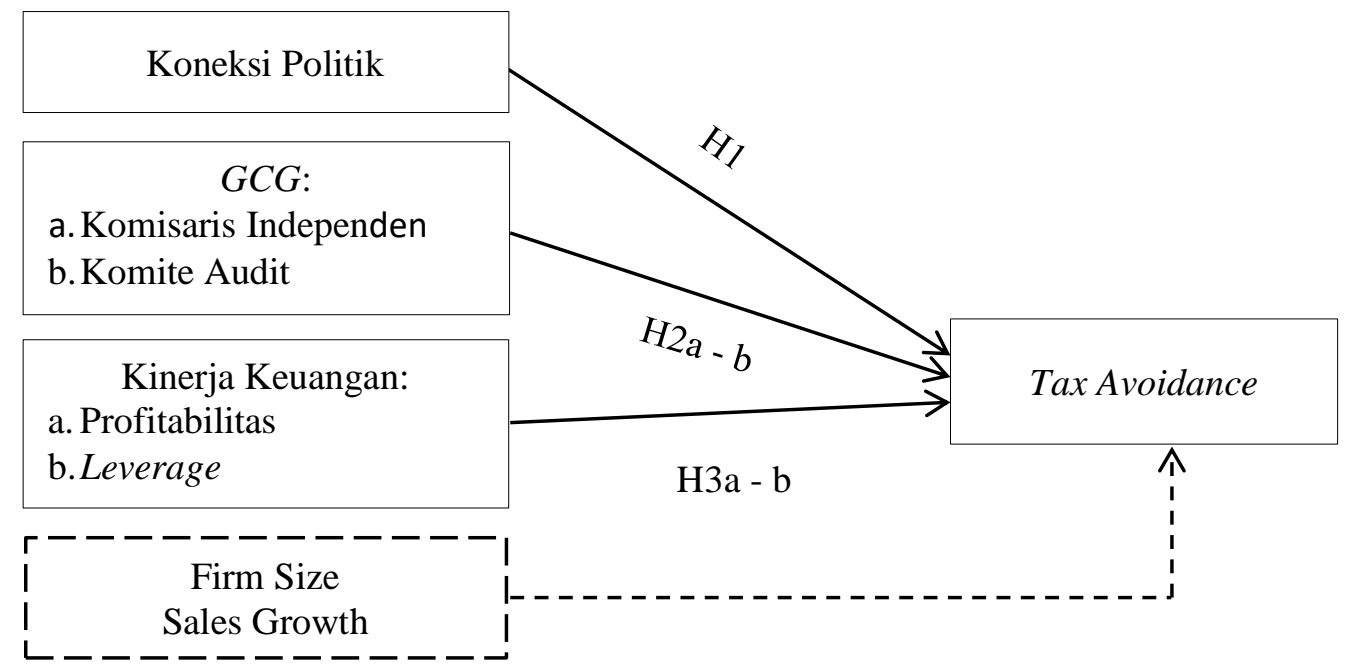

Gambar 1. Kerangka Pikir

\section{METODE PENELITIAN}

Penelitian ini dilakukan pada perusahaan manufaktur yang terdaftar di Bursa Efek Indonesia (BEI) dan yang memberikan informasi laporan keuangan pada situs resminya di www.idx.co.id. Populasi yang digunakan dalam penelitian ini adalah perusahaan manufaktur yang terdaftar di Bursa Efek Indonesia tahun 2014-2018, menggunakan metode purposive sampling. 


\section{JURNAL AKUNTANSI, Vol. 9, No. 2, November (2020)}

Tabel 2. Kriteria Penentuan Sampel

\begin{tabular}{|l|c|}
\hline \multicolumn{1}{|c|}{ Kriteria } & Jumlah \\
\hline Perusahaan manufaktur yang terdaftar di BEI & 162 \\
\hline Perusahaan manufaktur yang mengalami delisted & $(3)$ \\
\hline Perusahaan dengan annual report tidak lengkap & $(56)$ \\
\hline Perusahaan yang menggunakan mata uang selain rupiah & $(22)$ \\
\hline Perusahaan dengan nilai laba negative & $(36)$ \\
\hline \multicolumn{1}{|c|}{ Jumlah Sampel Menyeluruh } & $\mathbf{4 5}$ \\
\hline
\end{tabular}

Sumber : data diolah, 2020

Dalam penelitian ini dapat dibentuk persamaan :

Model I :

CETR $=\alpha+\beta_{1} \mathrm{KP}+\beta_{2} \mathrm{BOARD}+\beta_{3}$ AUDIT $+\beta_{4} \mathrm{ROA}+\beta_{5} \mathrm{DAR}+\beta_{6} \mathrm{SIZE}+\beta_{7}$ GROWTH $+\mathrm{e}$

Dimana :

\begin{tabular}{|c|c|}
\hline CETR & $=$ Tax Avoidance \\
\hline$\alpha$ & = Nilai konstan (alpha) \\
\hline$\beta$ & $=$ Koefisien regresi \\
\hline KP & $=$ Koneksi Politik \\
\hline BOARD & $=$ Komisaris Independen \\
\hline AUDIT & $=$ Komite Audit \\
\hline ROA & $=$ Return On Assets \\
\hline DAR & $=$ Leverage \\
\hline SIZE & $=$ Firm Size \\
\hline GROWTH & $=$ Sales Growth \\
\hline$e$ & $=$ Standar Error \\
\hline
\end{tabular}

Dasar pengujian hipotesis menggunakan perbandingan ttabel dengan tsatistik atau p-value (Wati, 2018). Jika P-value < 0,05 maka hipotesis penelitian diterima.

\section{ANALISIS DATA}

Tabel 3. Deskripsi Variabel Penelitian

\begin{tabular}{|l|c|c|c|c|}
\hline \multirow{2}{*}{ Variabel } & \multicolumn{4}{c|}{$\mathrm{N}=240$} \\
\cline { 2 - 5 } & Min & Max & Mean & ST. DEV \\
\hline CETR & -32.1856375 & 1.141362123 & -0.26845858 & 2.2351378 \\
\hline KP & 0 & 1 & 0.444444444 & 0.498011920 \\
\hline BOARD_INDEP & 0.2 & 1 & 0.419389425 & 0.118437434 \\
\hline KOM_AUDIT & 0.125 & 0.666666667 & 0.319823732 & 0.119698235 \\
\hline ROA & -0.548466479 & 0.920997195 & 0.065686972 & 0.139666524 \\
\hline DAR & 0.027523764 & 3.593280344 & 0.481932577 & 0.426701287 \\
\hline SIZE & 25.29535218 & 33.4737275 & 28.27068265 & 1.720896612 \\
\hline SALES & -0.986759075 & 6.42530212 & 0.122317751 & 0.635983894 \\
\hline
\end{tabular}

Sumber: Data BEI diolah, 2020 
Variabel tax avoidance yang dihitung dengan CETR memiliki nilai terendah (minimum) sebesar -32.18 pada PT. Malindo Feedmill Tbk tahun 2017, nilai tertinggi (maximum) sebesar 1.14 pada PT. Prasidha Aneka Niaga Tbk tahun 2018, nilai rata-rata (mean) sebesar -0.26 dan nilai standar deviasi sebesar 2.23. Koneksi politik yang menggunakan variabel dummy yang nilainya hanya 1 dan 0 , sehingga nilai terendah adalah 0 , nilai tertinggi 1 , nilai rata-rata sebesar 0,41 dan standar deviasi sebesar 0,12. Nilai KOM_AUDIT terendah (minimum) sebesar 0,125 pada PT. Keramika Indonesia Assosiasi Tbk tahun 2017, nilai tertinggi (maximum) sebesar 0.66 pada PT. Gudang Garam Tbk tahun 2016, PT. Bentoel Internasional Investama Tbk tahun 2018, PT. Arwana Citramulia Tbk tahun 2014, nilai rata-rata (mean) sebesar 0.31 dan nilai standar deviasi sebesar 0.12. Nilai ROA terendah (minimum) sebesar -0.55 pada PT. Keramik Aalamsari Industri Tbk tahun 2016, nilai tertinggi (maximum) sebesar 0.92 pada PT. Merck Tbk tahun 2018, nilai rata-rata (mean) sebesar 0.06 dan nilai standar deviasi sebesar 0.14. Nilai DAR terendah (minimum) sebesar 0.027 pada PT. Pyridam Farma Tbk tahun 2014, nilai tertinggi (maximum) sebesar 3.59 pada PT. Jakarta Kyoel Steel Tbk tahun 2018, nilai rata-rata (mean) sebesar 0.48 dan nilai standar deviasi sebesar 0.42. Nilai SIZE terendah (minimum) sebesar 25.29 pada PT. Kedaung Indan Can Tbk tahun 2014, nilai tertinggi (maximum) sebesar 33.47 pada PT. Astra Internasional Tbk tahun 2018, nilai rata-rata (mean) sebesar 28.27, dan nilai standar deviasi sebesar 1.72. Nilai SALES adalah nilai terendah (minimum) sebesar -0.98 pada PT. Jakarta Kyoel Steel Tbk tahun 2018, nilai tertinggi (maximum) sebesar 6.42 pada PT. Daria Varia Labortoria Tbk tahun 2018, nilai rata-rata (mean) sebesar 0.12, dan nilai standar deviasi sebesar 0.63.

Tabel 3. Hasil Pengujian Model Penelitian Hasil Regresi EGLS

\begin{tabular}{ccccc}
\hline \hline Variable & Coefficient & $\begin{array}{c}\text { Std. } \\
\text { Error }\end{array}$ & $\begin{array}{c}\mathrm{t}- \\
\text { Statistic }\end{array}$ & Prob. \\
\hline \hline & & & & \\
C & -0.67775 & 0.391283 & -1.73213 & 0.0847 \\
KP & 0.195794 & 0.035181 & 5.565257 & 0.0000 \\
BOARD & -0.46083 & 0.253497 & -1.81788 & 0.0705 \\
AUDIT & 0.185761 & 0.187757 & 0.989366 & 0.3236 \\
ROA & 0.638098 & 0.189633 & 3.36491 & 0.0009 \\
DER & 0.085071 & 0.034158 & 2.490556 & 0.0135 \\
SIZE & 0.016273 & 0.013059 & 1.246109 & 0.2141 \\
GROWTH & -0.00928 & 0.033611 & -0.27609 & 0.7827 \\
\hline \hline
\end{tabular}

Sumber : Eviews data diolah, 2020

\section{HASIL DAN PEMBAHASAN}

Berdasarkan koefisien regresi yang diperoleh dari pengaruh variabel koneksi politik terhadap tax avoidance adalah sebesar 0.195794 dengan nilai $\mathrm{t}_{\text {statistik }} 5.565257>1.96$ pada taraf signifikan $\alpha=0,01(1 \%)$ dengan nilai signifikansi sebesar $0.0000<0.01$ yang menyatakan bahwa koneksi politik berpengaruh positif dan signifikan terhadap tax avoidance. Hasil ini mendukung penelitian yang dilakukan oleh Butje dan Tjondro (2014), Munawaroh dan Ramdany (2019) yang sama- sama menemukan bahwa koneksi politik memiliki pengaruh positif terhadap potensi tax avoidance. Hal ini menunjukkan bahwa perusahaan manufaktur yang mayoritas dimiliki oleh orang- orang yang berkepentingan di pemerintahan memiliki pengaruh kuat untuk melakukan potensi tax avoidance. 
Koefisien regresi yang diperoleh dari pengaruh variabel komisaris independen terhadap tax avoidance adalah sebesar -0.460827 dengan nilai $\mathrm{t}_{\text {statistik }}-1.817877<1.96$ pada taraf signifikan $\alpha=0,05(5 \%)$ dengan nilai signifikansi sebesar $0.0705>0.05$ yang menyatakan bahwa terdapat pengaruh negatif tidak signifikan antara komisaris independen terhadap tax avoidance. Hasil ini mendukung penelitian yang dilakukan Prakosa (2014), Diantari dan Ulupui (2016) Wijayanti dan Merkusiwati (2017) yang menyatakan komisaris independen berpengaruh negatif terahadap tax avoidance. Maka komisaris independen mampu mengontrol dan mengendalikan keinginan pihak manajemen perusahaan untuk melakukan penghematan pajak, menurunkan biaya keagenan sehingga membuat praktik tax avoidance menurun.

Koefisien regresi yang diperoleh dari pengaruh variabel komite audit terhadap tax avoidance adalah sebesar 0.185761 dengan nilai $\mathrm{t}_{\text {statistik }} 0.989366<1.96$ pada taraf signifikan $\alpha=$ 0.1 (10\%) dengan nilai signifikansi sebesar $0.3236>0.1$ yang menyatakan bahwa terdapat pengaruh positif antara komite audit terhadap tax avoidance. Hasil pengujian terhadap hipotesis ditolak. Hasil ini didukung oleh peneliti sebelumnya yaitu Marfiah \& Syam (2016) yang menguji pengaruh komite audit terhadap tax avoidance, dan hasilnya menyatakan bahwa komite audit berpengaruh positif terhadap tax avoidance. Hal ini menunjukkan bahwa Semakin sering komite audit melakukan rapat, maka diduga terdapat kemungkinan untuk mendiskusikan upayaupaya tax avoidance dalam rangka tujuan tertentu.

Koefisien regresi yang diperoleh dari pengaruh variabel profitabilitas terhadap tax avoidance adalah sebesar 0.638098 dengan nilai tstatistik $3.364910<1.96$ pada taraf signifikan $\alpha=0,01$ (1\%) dengan nilai signifikansi sebesar $0.0009<0.01$ yang menyatakan bahwa terdapat pengaruh positif dan signifikan antara profitabilitas terhadap tax avoidance. Hasil ini mendukung penelitian yang dilakukan oleh Dewinta dan Setiawan (2016), dan Reinaldo (2017) mengatakan bahwa profitabilitas berpengaruh positif terhadap tax avoidance. Hal ini menunjukkan bahwa ketika laba yang diperoleh membesar, maka jumlah pajak penghasilan akan meningkat sesuai dengan peningkatan laba perusahaan.

Koefisien regresi yang diperoleh dari pengaruh variabel leverage terhadap tax avoidance adalah sebesar 0.085071 dengan nilai tstatistik $2.490556<1.96$ pada taraf signifikan $\alpha=0.01$ (1\%) dengan nilai signifikansi sebesar $0.0135=0.01$ yang menyatakan bahwa terdapat pengaruh positif dan signifikan antara leverage terhadap tax avoidance. Hasil pengujian terhadap hipotesis ditolak. Hasil ini didukung oleh peneliti sebelumnya yaitu Annisa (2017), Pajriyansyah dan Firmansyah (2017), dan Nafis, dkk (2018) melakukan penelitian mengenai pengaruh leverage terhadap tax avoidance yang hasilnya membuktikan bahwa leverage berpengaruh positif terhadap tax avoidance. Sehingga perusahaan dengan tingkat leverage yang tinggi memiliki kemampuan yang lebih untuk menghindari pajak melalui transaksi-transaksi keuangan.

Dan variabel kontrol yaitu firm size yang berpengaruh positif terhadap tax avoidance dan sales growth yang berpengaruh negatif terhadap tax avoidance.

\section{PENUTUP}

Secara empiris, hasil penelitian ini menunjukkan bahwa faktor yang menentukan penghindaran pajak pada perusahaan adalah koneksi politik dan kinerja keuangan. Hal ini menunjukkan bahwa perusahaan manufaktur yang mayoritas dimiliki oleh orang- orang yang berkepentingan di pemerintahan memiliki pengaruh kuat untuk melakukan potensi tax avoidance dan ketika laba yang diperoleh membesar, maka jumlah pajak penghasilan akan meningkat sesuai dengan peningkatan laba perusahaan. Corporate Governance bukanlah faktor penentu dari penghindaran pajak pada perusahaan. komisaris independen dan komite audit mampu mengontrol dan mengendalikan keinginan pihak manajemen perusahaan untuk melakukan penghematan pajak, menurunkan biaya keagenan sehingga membuat praktik tax avoidance menurun. 


\section{REFERENSI}

Annisa. 2017. "Pengaruh Return On Asset, Leverage, Ukuran Perusahaan dan Koneksi Politik Terhadap Penghindaran Pajak (Studi Empiris Pada Perusahaan Manufaktur yang Terdaftar di BEI Periode Tahun 2012-2015)" dalam Jom Fekon Vol. 4 No. 1. Pekanbaru : Fakultas Ekonomi Universitas Riau.

Arianandini, Putu Winning., dan Wayan Ramantha. 2018. "Pengaruh Profitabilitas, Leverage, dan Kepemilikan Institusional Pada Tax Avoidance" dalam E-Jurnal Akuntansi Universitas Udayana Vol.22.3. Bali : Fakultas Ekonomi dan Bisnis Universitas Udayana.

Butje, Stella., dan Elisa Tjondro. 2014. "Pengaruh Karakter Eksekutif Dan Koneksi Politik Terhadap Tax Avoidance" dalam Tax \& Accounting Review, Vol. 4, No. 2. Jakarta: Jurusan Akuntansi Pajak Universitas Kristen Petra.

Cahyono, Deddy Dyas., Rita Andini dan Kharis Raharjo. 2016. "Pengaruh Komite Audit, Kepemilikan Institusional, Dewan Komisaris, Ukuran Perusahaan (Size), Leverage (DER) Dan Profitabilitas (ROA) Terhadap Tindakan Penghindaran Pajak (Tax Avoidance) Pada Perusahaan Perbankan Yang Listing BEI Periode Tahun 2011 -2013” dalam Journal Of Accounting, Volume 2 No.2.

Chen, K. P dan Chu, C. Y. C. 2010. Internal Control vs External Manipultion: A Model of Courporate Income Tax Evasion. Rand Journal of Economics.

Christensen, D. M., Dhaliwal, D. S., Boivie, S., \& Graffin, S. D. (2014). Top Management Conservatism And Corporate Risk Strategies: Evidence From Managers' Personal Political Orientation And Corporate Tax Avoidance. Strategic Management Journal.

Dewinta, I.A.R., Putu Ery S. (2018). Pengaruh Ukuran Perusahaan, Umur Perusahaan, Profitabilitas, Leverage, Dan Pertumbuhan Penjualan Terhadap Tax Avoidance. E-Jurnal Akuntansi Universitas Udayana Vol.14.3.

Dharma, Made Surya., dan Putu Agus Dharma. 2016. "Pengaruh Leverage, Intensitas Aset Tetap, Ukuran Perusahaan, dan Koneksi Politik Terhadap Tax Avoidance" dalam EJurnal Akuntansi Universitas Udayana Vol.15.1. Bali : Fakultas Ekonomi dan Bisnis Universitas Udayana.

Diantari, P.R. \& IGK Agung Ulupui (2016). Pengaruh Komite Audit, Proporsi Komisaris Independen, Dan Proporsi Kepemilikan Institusional Terhadap Tax Avoidance. E-Jurnal Akuntansi Universitas Udayana Vol.16.1

Fadila, Melisa. 2017. "Pengaruh Return On Asset, Leverage, Ukuran Perusahaan Kompensasi Rugi Fiskal, Kepemilikan Institusional, dan Koneksi Politik Terhadap Penghindaran Pajak (Studi Empiris Pada Perusahaan Manufaktur yang Terdaftar di BEI Tahun 20112015)" dalam Jom Fekon, Vol. 4 No. 1. Pekanbaru : Fakultas Ekonomi Universitas Riau.

Fahmi, Irham. 2012. Analisis Kinerja Keuangan. Bandung: Alfabeta.

(2013). Etika Bisnis: Teori, Kasus dan Solusi. Bandung: Alfabeta.

(2015). Etika Bisnis, Buku ke 3. Revisi. Bandung: Alfabeta

Fajar, Mohammad. (2018). Pengaruh Profitabilitas, Leverage, Dan Corporate Governance Terhadap Tax Avoidance (Studi Empiris Pada Perusahaan Manufaktur Yang Terdaftar Di Bursa Efek Indonesia Periode 2012-2014). Faculty Of Economics And Business, Riau University, Pekanbaru, Indonesia. Volume 1 Edisi 1

Faizah, Siti Nur., Vidya Vitta A. (2017). Pengaruh Return On Asset, Leverage, Kepemilikan Institusional Dan Ukuran Perusahaan Terhadap Tax Avoidance. Program Studi Akuntansi, Fakultas Ekonomi Universitas PGRI Yogyakarta. Jurnal Akuntansi Vol. 5 No. 2

Feranika, Ayu. (2018). Pengaruh Kepemilikan Institusional, Dewan Komisaris Independen, Kualitas Audit, Komite Audit, Karakter Eksekutif, Dan Leverage Terhadap Tax Avoidance. Jurnal Akuntansi. Pascasarjana Universitas Jambi.

Fitria, Ulan. (2018). Analisis Perbedaan Kinerja Keuangan Sebelum Dan Sesudah Diberlakukannya Tax Amnesty (Studi Empiris Pada Perusahaan Real Estate Dan Property Yang Terdaftar Di Bursa Efek Indonesia BEI Periode 2015-2016). Skripsi. Jurusan 
Akuntansi. Fakultas Ekonomi Dan Bisnis Institut Informatika Dan Bisnis Darmajaya Bandar Lampung.

Handayani, D., dan Wulandari, H., 2014, Pengaruh Kepemilikan Pemerintah dan Ukuran Perusahaan Terhadap Tarif Pajak Efektif Perusahaan, Jurnal Akuntansi Keuangan dan Bisnis, Vol. 7, Desember 2014.

Harto, Puji dan Puspita, Ratih Silvia. 2014. Pengaruh Tata Kelola Perusahaan terhadap Penghindaran Pajak. Diponegoro Journal of Accounting.

Ichsan, R. (2013, Januari 12). Teori Keagenan. Retrieved April 1, 2019, From Https://Bungrandhy.Wordpress.Com/2013/01/12/Teori-Keagenan-Agency-Theory/

Ikatan Akuntansi Indonesia. 2012. Standar Akuntansi Keuangan. PSAK. Cetakan ke Empat, Buku Satu, Jakarta: Penerbit Salemba Empat.

Kasmir, 2014. Analisis Laporan Keuangan, Edisi Pertama, Cetakan Ketujuh. Jakarta: PT. Rajagrafindo Persada.

Kim, C. F., \& Zhang, L. (2013). Corporate Political Connections And Tax Aggressiveness. Contemporary Accounting Research, Forthcoming.

2015. Corporate Politicals Connections and Tax Aggressiveness. Contemporary Accounting Research, Forthcoming.

Kurniasih, T., \& Sari, M. M. R. 2013. Pengaruh Return On Assets, Leverage, Corporate Governance, Ukuran Perusahaan dan Kompensasi Rugi Fiskal pada Tax Avoidance.

Li, C., Wang, T., Wu, L. dan Xiao, J. Z. 2013. Political'sConnections and Tax-Induced Earnings Management: Evidence from China. The European Journal of Finance 20: 1-19.

Madona, Yulia., Trisnadi Wijaya. (2018). Pengaruh Karakter Eksekutif, Komite Audit dan Profitabilitas Terhadap Tax Avoidance (Studi Empiris Perusahaan Manufaktur yang Terdaftar Di BEI Tahun 2012-2016). Jurusan Akuntansi STIE Multi Data Palembang.

Marfirah, D., \& Fazli Syam BZ. (2016). Pengaruh Corporate Governance dan Leverage terhadap Tax Avoidance pada Perusahaan Manufaktur yang Terdaftar di Bursa Efek Indonesia (BEI) Tahun 2011-2015. Jurnal Ilmiah Mahasiswa Ekonomi Akuntansi, 1(2), 91-102.

Marfu'ah, Laila. 2015. Pengaruh Return On Asset, Leverage, Ukuran Perusahaan Kompensasi Rugi Fiskal Dan Koneksi Politik Terhadap Tax Avoidance. Skripsi Universitas Muhammadiyah Surakarta.

Mayangsari, Cindy. 2015. "Pengaruh Kompensasi Eksekutif, Kepemilikan Saham Eksekutif, Preferensi Risiko Eksekutif dan Leverage Terhadap Penghindaran Pajak (Tax Avoidance)" dalam Jom Fekon Vol.2 No.2. Pekanbaru : Fakultas Ekonomi Universitas Riau.

Mughal, Muhammad Muazzam and Akram , Muhammad. 2012. "Reasons of Tax Avoidance and Tax Evasion: Reflections from Pakistan", Journal of Economic and Behavioral Studies, Volume 4.

Mulyani, Sri.dkk. 2013. "Pengaruh Karakteristik Perusahaan, Koneksi Politik dan Reformasi Perpajakan terhadap Penghindaran Pajak (Studi pada Perusahaan Manufaktur yang terdaftar di BEI tahun 2008 s.d 2012)." Jurnal PS Perpajakan, Jurusan Administrasi Bisnis, Fakultas Ilmu Administrasi. Malang: Universitas Brawijaya.

Munawaroh, M.A. \& Ramdany. (2019). Peran CSR, Ukuran Perusahaan, Karakter Eksekutif dan Koneksi Politik Terhadap Potensi Tax Avoidance. Jurnal Akuntansi STIE Muhammadiyah Jakarta. Vol. 8 No. 2. Pp 109-121.

Munawir. 2012. Analisis Informasi Keuangan. Yogyakarta: Liberty.

Murniyana, W G. 2018. "Pengaruh Koneksi Politik, Harga Transfer, Leverage dan Pertumbuhan Penjualan Terhadap Penghindaran Pajak". Fakultas Ekonomi Universitas Islam Indonesia Yogyakarta.

Oktamawati, Mayarisa. 2017. "Pengaruh Karakter Eksekutif, Komite Audit, Ukuran Perusahaan, Leverage, Pertumbuhan Penjualan, dan Profitabilitas Terhadap Tax Avoidance" dalam Jurnal Akuntansi Bisnis, Vol. XV No. 30. Semarang : Universitas Katolik Soegijapranata. 
Pajriyansyah, Ridwan., dan Amrie Firmansyah. 2017. "Pengaruh Leverage, Kompensasi Rugi Fiskal dan Manajemen Laba Terhadap Penghindaran Pajak". Jakarta: Politeknik Keuangan Negara STAN Indonesia.

Prakosa, Bambang Kesit, 2014. "Pengaruh Profitabilitas, Kepemilikan Keluarga dan Corporate Governance Terhadap Penghindaran Pajak di Indonesia.” SNA 17 Mataram Lombok Universitas Mataram.

Prebble, Z. M., \& Prebble, J. (2010). The Morality Of Tax Avoidanc

Purwoto, Lukas. 2011. Pengaruh Koneksi Politis, Kepemilikan Pemerintah dan Keburaman Laporan Keuangan terhadap Kesinkronan dan Risiko Crash Harga Saham. Ringkasan Disertasi Program Doktor Ilmu Ekonomi Manajemen. Universitas Gadjah Mada.

Sari, Kartika \& Rawidjo. (2019). Pengaruh Corporate Governance, Koneksi Politik Dan Profitabilitas Terhadap Potensi Tax Avoidance. Jurnal Akuntansi STIE Muhammadiyah Jakarta. Vol. 9 No. 1.

Sari, Meila \& Heidy Paramitha Devi. (2018). Pengaruh Corporate Governance Dan Profitabilitas Terhadap Tax Avoidance. Jurnal Akuntansi Universitas PGRI Madiun. Vol. 2, No.2

Sartori, Nicola. 2010. Effect of Strategic Tax Behaviors on Corporate Governance. www.ssrn.com

Setiani, C. J. (2016). Analisis Faktor-Faktor Yang Mempengaruhi Tax Avoidance. Universitas Lampung, Bandar Lampung.

Sugiyarti, S. M. P. L. (2017). Pengaruh Intensitas Aset Tetap , Pertumbuhan Penjualan dan Koneksi, 5(3), 1625-1641.

Swingly, Calvin dan Sukartha, I Made. 2015. Pengaruh Karakter Eksekutif, Komite Audit, Ukuran Perusahaan, Leverage dan Sales Growth pada Tax Avoidance. E-Journal Akuntansi Universitas Udayana, 10(1), pp: 47-62.

Syuhada, Anggi., Yusnaini Y. dan Eka Meirawati. (2019). Pengaruh Good Corporate Governance Dan Profitabilitas Terhadap Tax Avoidance Pada Sektor Pertambangan. Jurnal Penelitian dan Pengembangan Akuntansi Vol. 13 No. 2.

Utari, Ni Kadek Yuliani., dan Ni Luh Supadmi. 2017. " Pengaruh Corporate Governance, Profitabilitas dan Koneksi Politik Pada Tax Avoidance” dalam E-Jurnal Akuntansi Universitas Udayana Vol.18.3. Bali : Fakultas Ekonomi dan Bisnis Universitas Udayana.

Wati, L.N., Primiana, I. and Sudarsono, R. 2016. Political connections of conglomerates: evidence from Indonesia Stock Exchange. Actual Problems of Economics. (12), pp.110119.

Wati, L. N. (2017). Board of commissioner's effectiveness on politically connected conglomerates: Evidence from Indonesia. Pertanika Journal Social Sciences \& Humanities, 25(S), pp. 255-270.

Wati, L. N.; Primiana, H. I.; Pirzada, K.; Sudarsono, R. 2019. Political connection, block holder ownership and performance, Entrepreneurship and Sustainability Issues 7(1): 52-68.

Wati, L. N., Ramdany, Momon. 2020. Does Corporate Governance Affect Financial Reporting Quality Of Politically Connected Firms? Entrepreneurship and Sustainability Issues 7(3): pp. 2126-2143.

Wijayanti, Y. C., \& Merkusiwati, N. K. L. A. (2017). Pengaruh Proporsi Komisaris Independen, Kepemilikan Institusional, Leverage, dan Ukuran Perusahaan Pada Penghindaran Pajak. E-Jurnal Akuntansi Universitas Udayana, 20(1).

Winata, Fenny. 2014. Pengaruh Corporate Governance Terhadap Tax Avoidance pada Perusahaan yang Terdaftar di Bursa Efek Indonesia Tahun 2013. Tax \& Accounting Review (Vol. 4, No.1, 2014)

Zain, Mohammad. (2008) Manajemen Perpajakan, Edisi 3. Jakarta: Penerbit Salemba Empat. finance.detik.com

pajak.go.id

www.idx.co.id 